\title{
Common name: mourning cloak (known in the United Kingdom as the Camberwell beauty) Nymphalis antiopa (Linnaeus) (Insecta: Lepidoptera: Nymphalidae: Nymphalinae) ${ }^{1}$
}

\author{
Donald W. Hall and Jerry F. Butler ${ }^{2}$
}

\section{Introduction}

The mourning cloak, Nymphalis antiopa (Linnaeus), is a large distinctive butterfly and is one of our most widely distributed butterfly species. In northern areas where it overwinters, adults may be seen basking in the sun during almost every month of winter on warm days. The upper surfaces of the wings are very beautiful, but at rest with the wings closed, the mourning cloak is highly cryptic. In the United Kingdom it is known as the Camberwell beauty.

\section{Distribution}

The mourning cloak is widespread from Alaska south to Venezuela and throughout Eurasia-rarely reaching England (Scott 1986). It is unlikely that mourning cloaks are permanent residents of Florida. Adult mourning cloaks have been observed infrequently in a number of locations in north central Florida and the Florida Panhandle (Jue \& Jue 2011, Minno \& Powell 2011). Repeated sightings of what appear to be recently emerged adults have been made in certain years (e.g., 2000 and 2011) with no sightings in intervening years. Mourning cloaks may occasionally breed in northern Florida, but most adult specimens found here have been believed to be winter migrants from farther north (Glassberg et al. 2000).

Kimball (1965) cited a record (Anonymous 1938) of mourning cloak caterpillars on Rumex acetosella in Alachua County, Florida, but this citation was inaccurate. Kimball confused reports of woolly bears on Rumex with a report of mourning cloaks from Colorado that appeared on the same page. Unfortunately, this erroneous report has been perpetuated in the butterfly literature.

The first documented instance of mourning cloak caterpillars in Florida occurred in March 2011 in Alachua County, when approximately 50 mature larvae were observed climbing down a large sugarberry tree, Celtis laevigata (Boisduval \& Leconte) (Minno \& Powell 2011). In addition to this being the first instance of breeding in Florida, it is also the first record of the mourning cloak feeding on sugarberry.

1. This document is EENY-451, one of a series of Featured Creatures from the Entomology and Nematology Department, Florida Cooperative Extension Service, Institute of Food and Agricultural Sciences, University of Florida. Published: June 2009. Revised December 2011 This document is also available on Featured Creatures website at http://entomology.ifas.ufl.edu/creatures. Please visit the EDIS website at http://edis.ifas.ufl.edu. Additional information on these organisms, including many color photographs, is available at the Entomology and Nematology Department website at http:// entnemdept.ifas.ufl.edu/

2. Donald W. Hall, professor and Jerry F. Butler, professor, Entomology and Nematology Department, Institute of Food and Agricultural Sciences, University of Florida, Gainesville, FL. 


\section{Description}

\section{Adults}

The wing spread of adults is approximately 3.0 inches. The upper surface of the wings is deep maroon with a sub-marginal black band containing a series of powder blue spots and a yellow marginal band. The ventral side of the wings is black - resembling charred wood and with a marginal whitish-yellow band.

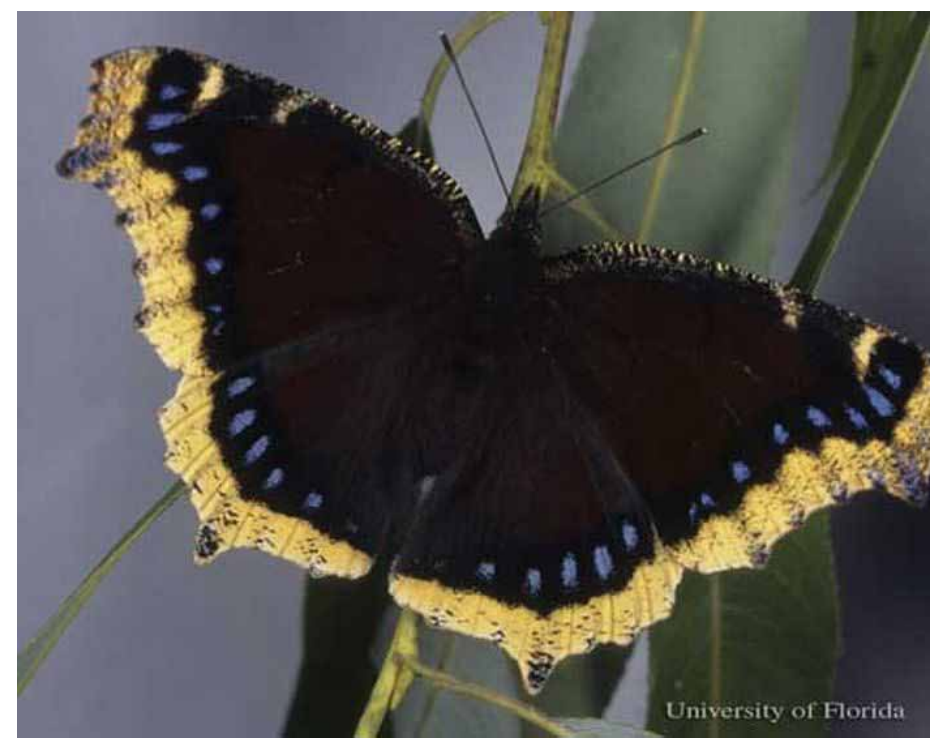

Figure 1. Dorsal view of wings of an adult mourning cloak, Nymphalis antiopa (Linnaeus), reared from larva collected by Don Hall in Beltrami County, Minnesota.

Credits: Jerry Butler, University of Florida

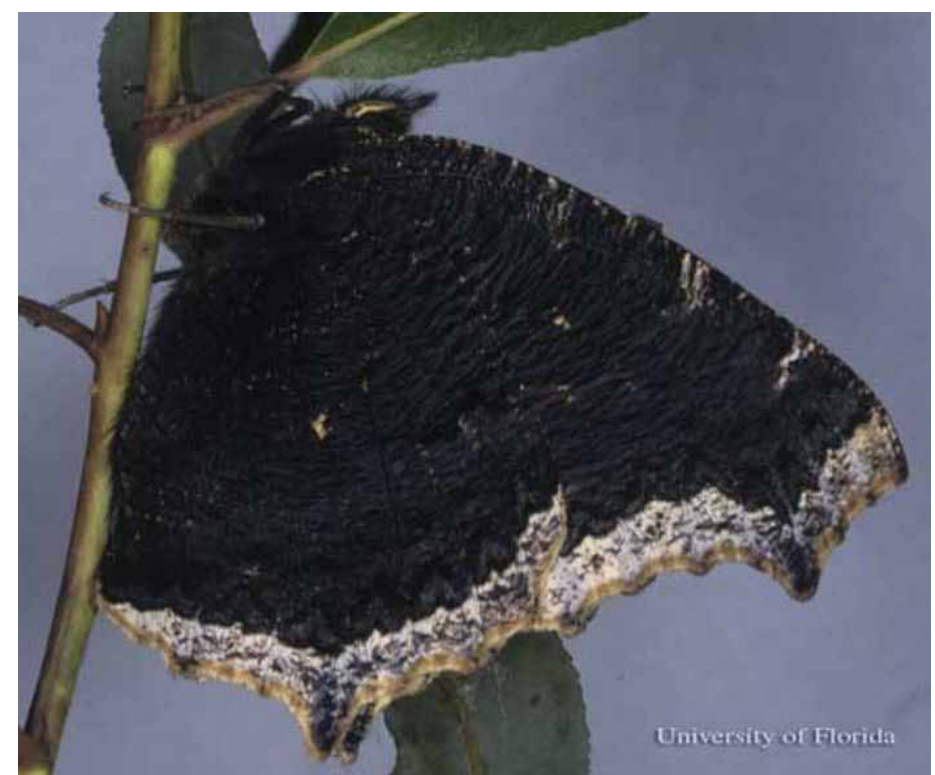

Figure 2. Ventral view of wings of an adult mourning cloak, Nymphalis antiopa (Linnaeus), reared from larva collected by Don Hall in Beltrami County, Minnesota.

Credits: Jerry Butler, University of Florida

\section{Eggs}

Eggs are whitish but darken prior to hatching (Scott 1986). Photographs of eggs and young larvae can be found at Warren et al. (2009).

\section{Larvae}

Full grown larvae are approximately 2.0 inches in length (Minno et al. 2005). The head is black with white hairs. The body is black, covered with small white dots and numerous white hairs. There is a transverse row of stout branched spines (scoli) on each segment, and most segments have a mid-dorsal reddish orange patch.

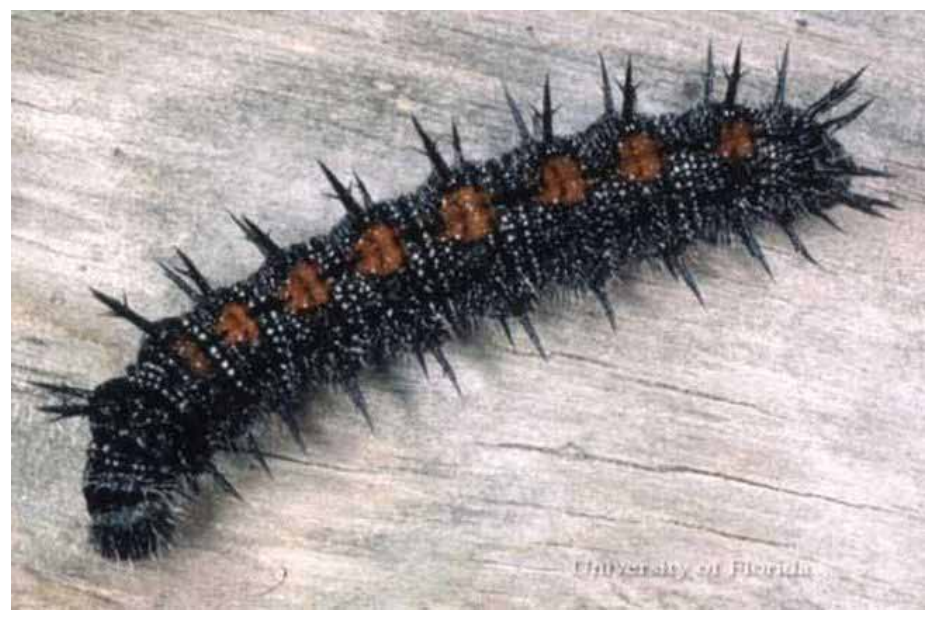

Figure 3. Larva of a mourning cloak, Nymphalis antiopa (Linnaeus), collected in Montgomery County, Virginia.

Credits: Don Hall, University of Florida

\section{Pupae}

Pupae are approximately 0.8 inches in length. They are gray with two rows of ventro-lateral, red-tipped, sharp points. The pupae hang vertically, attached by the terminal end to a small silk pad by the cremaster.

\section{Life Cycle and Biology}

There is a single generation per year in most areas and possibly a second generation southward. Unmated adults overwinter and mate and lay eggs in the spring. The adults are long-lived and live for nearly a year (Allen 1997, Wagner 2005). Males perch and defend territories and fly out to meet females. Adults are known for their graceful gliding behavior. Adults may feign death if attacked by predators (Cech and Tudor 2005).

Eggs are laid in large clusters in a single layer around the stems of the host plants (Scott 1986). The larvae are gregarious throughout their lives, feeding within silken webs as very young larvae (Allen 1997). When threatened, larvae twitch in unison-likely a defensive tactic to deter 


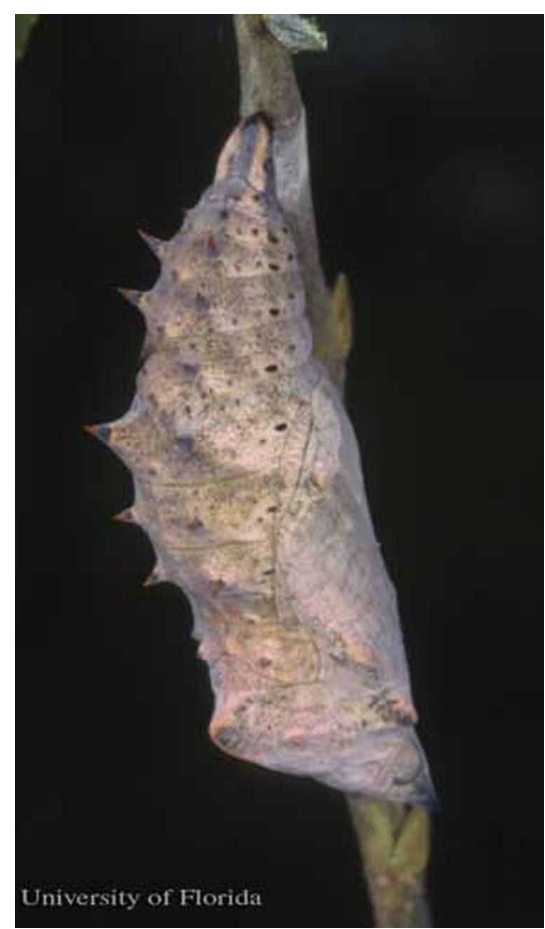

Figure 4. Pupa of a mourning cloak, Nymphalis antiopa (Linnaeus), reared from larva collected by Don Hall in Beltrami County, Minnesota. Credits: Jerry Butler, University of Florida

predators. Caterpillars mature in early summer and adults undergo aestivation (summer dormancy) (Young 1980).

Adults prefer tree sap and fermenting fruit but also visit mud and occasionally feed on flower nectar (Allen 1997, Opler and Krizek 1984, Scott 1986).

\section{Hosts}

Preferred plant hosts for larvae are mostly trees of many species in the family Salicaceae, particularly willows (Salix spp.), including the exotic weeping willow, and also poplars (Populus spp.). Members of the elm family Ulmaceae (Ulmus spp.) and hackberry family Celtidaceae (Celtis spp.) and less commonly a wide range of species representing a number of other families are also used (Scott 1986). Mature larvae often wander from the original host plant prior to pupation and are often reported from plant species on which they do not feed (Opler and Krizek 1984).

\section{Economic Importance}

In northern areas where it is common, mourning cloak caterpillars (sometimes called spiny elm caterpillars) may become pests on shade trees - seriously defoliating willows and elms and less frequently poplars, birches, hackberries and lindens, but they are readily controlled with insecticidal formulations of Bacillus thuringiensis (Johnson and Lyon 1988).

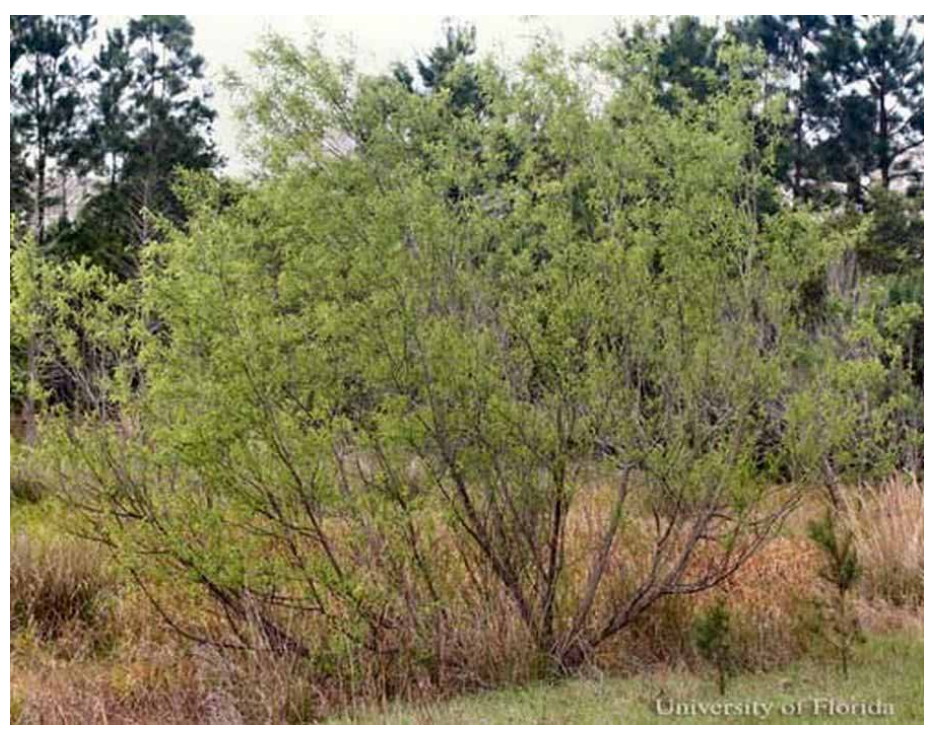

Figure 5. Carolina willow, Salix caroliniana Michx., a host of the mourning cloak butterfly, Nymphalis antiopa (Linnaeus).

Credits: Don Hall, University of Florida

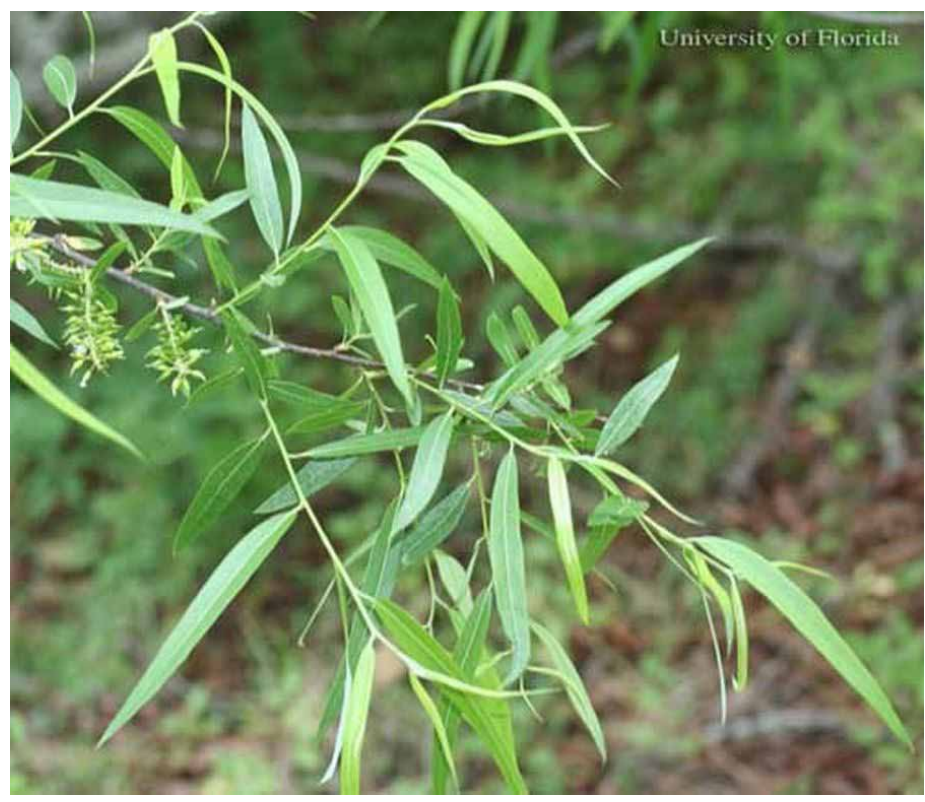

Figure 6. Carolina willow, Salix caroliniana Michx., a host of the mourning cloak butterfly, Nymphalis antiopa (Linnaeus).

Credits: Don Hall, University of Florida

\section{Selected References}

Allen TJ. 1997. The Butterflies of West Virginia and their Caterpillars. University of Pittsburgh Press. Pittsburgh, Pennsylvania. 388 pp.

Anonymous. 1938. Insect Pest Survey Bulletin. 18: 56.

Cech R, Tudor G. 2005. Butterflies of the East Coast: An Observer's Guide. Princeton University Press. Princeton, New Jersey. 345 pp.

Glassberg J, Minno MC, Calhoun JV. 2000. Butterflies through Binoculars - a Field, Finding, and Gardening 


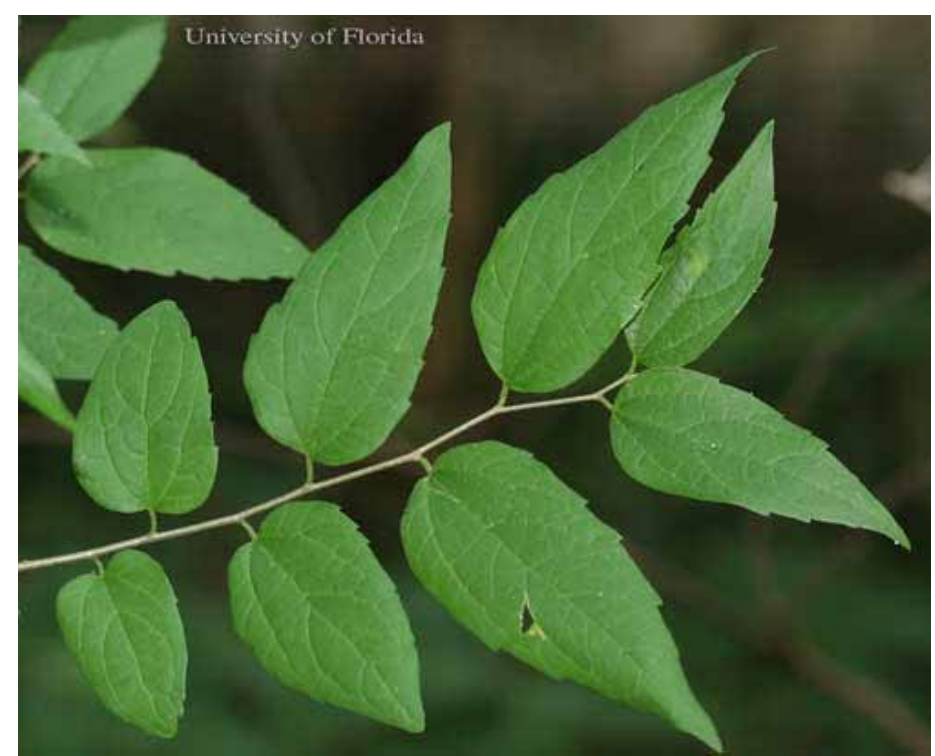

Figure 7. Sugarberry, Celtis laevigata Willd., a host of the mourning cloak butterfly, Nymphalis antiopa (Linnaeus) in Florida. Credits: Don Hall, University of Florida

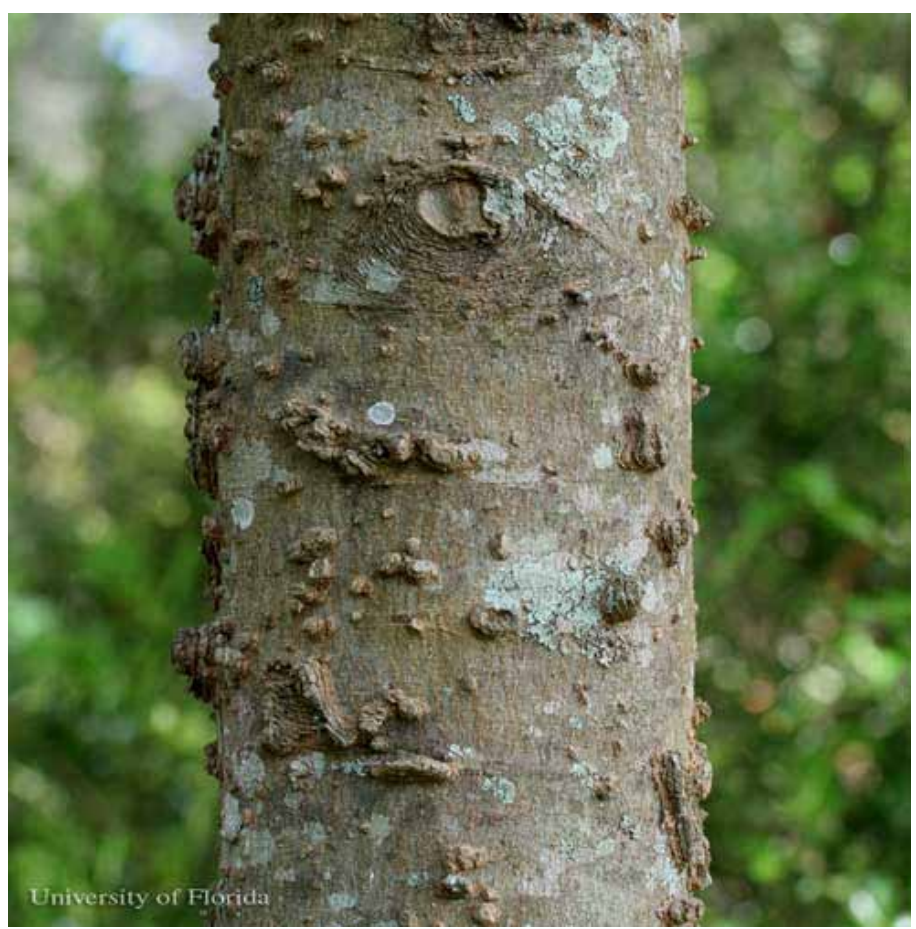

Figure 8. Warty trunk of the sugarberry, Celtis laevigata Willd., a host of the mourning cloak butterfly, Nymphalis antiopa (Linnaeus) in Florida. Credits: Don Hall, University of Florida

Guide to Butterflies in Florida. Oxford University Press, Inc. New York, New York. 242 pp.

Johnson WT, Lyon HH. 1988. Insects That Feed on Trees and Shrubs. Cornell University Press. Ithaca, New York. 2nd ed., $556 \mathrm{pp}$.

Jue DK, Jue SS. 2011. Evidence of mourning cloak (Nymphalis antiopa) breeding in northern Florida. Southern Lepidopterists' News 33: 89-90 \& 121-122.

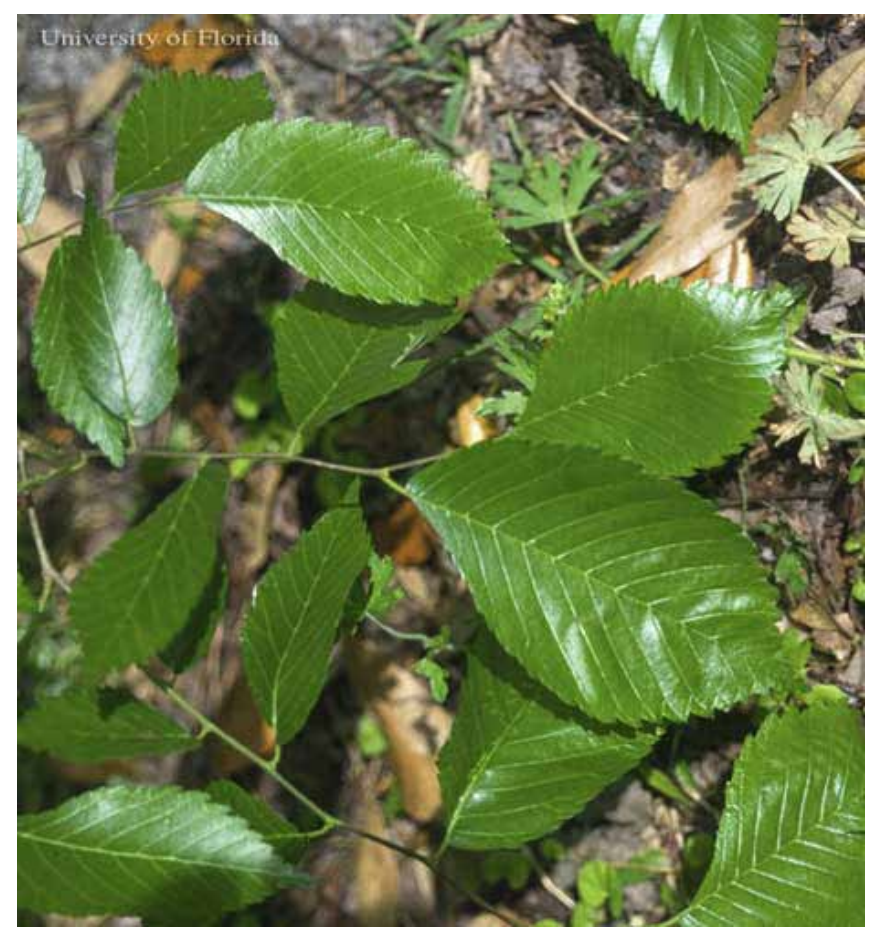

Figure 9. American elm, Ulmus americana L., a host of the mourning cloak butterfly, Nymphalis antiopa (Linnaeus).

Credits: Don Hall, University of Florida

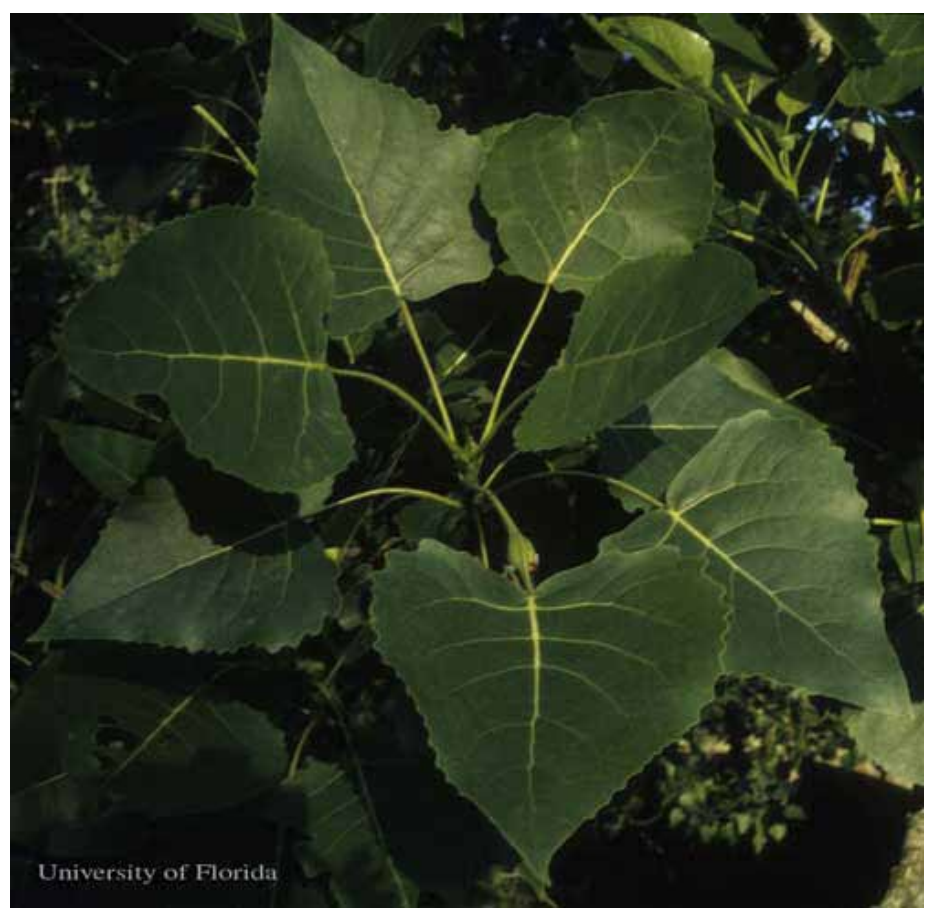

Figure 10. Eastern cottonwood, Populus deltoides W.Bartram ex Marshall, an occasional host of the mourning cloak butterfly, Nymphalis antiopa (Linnaeus).

Credits: Don Hall, University of Florida

Kimball CP, 1965. Lepidoptera of Florida. Florida Department of Agriculture. Arthropods of Florida and Neighboring Land Areas. 1: 363 pp. 
Minno MC, Butler JF, Hall DW. 2005. Florida Butterfly Caterpillars and their Host Plants. University Press of Florida. Gainesville, Florida. 341 pp.

Minno MC, Powell AC. 2011. Observations of the mourning cloak butterfly (Nymphalis antiopa) (Nymphalidae: Nymphalinae) in Alachua County, north-central Florida. Southern Lepidopterists' News 33: 104-106.

Opler PA, Krizek GO. 1984. Butterflies East of the Great Plains. The Johns Hopkins University Press. Baltimore, Maryland. 294 pp.

Scott JA. 1986. The Butterflies of North America: A Natural History and Field Guide. Stanford University Press. Stanford, California. 583 pp.

Warren WE, Davis K, Grishin NV, Pelham JP, Stangeland M. (2009). Nymphalis a. antiopa (mourning cloak). Interactive Listing of American Butterflies. http://butterfliesofamerica.com/nymphalis_antiopa.htm (8 May 2009).

Young AM. 1980.Some observations on the natural history and behavior of the Camberwell Beauty (Mourning Cloak) butterfly Nymphalis antiopa (Linnaeus) (Lepidoptera: Nymphalidae) in the United States. Entomologist's Gazette 31: 7-18. 